\title{
Respiratory mechanics in acute respiratory distress syndrome: a quality improvement based registry project
}

\author{
L Chen ${ }^{1,2^{*}}$, GQ Chen ${ }^{1,2,3}$, C Martins $^{4}$, K Porretta $^{4}$, O Shklar ${ }^{4}$, P Greco ${ }^{4}$, H Every ${ }^{4}$, M X $^{3}$, JX Zhou ${ }^{3}$, L Brochard $^{1,2}$ \\ From ESICM LIVES 2015 \\ Berlin, Germany. 3-7 October 2015
}

\section{Introduction}

The amount of pathophysiological impairment in patients with acute respiratory distress syndrome (ARDS) is variable and applying the same ventilator regimen to every patient is questionable. Monitoring of respiratory mechanics for the lung and chest wall allows an individualization of ventilator settings with a potential benefit for the patient. A registry with a large sample size will elicit helpful epidemiological information and may inform future recommendations. We therefore proposed a quality improvement (QI) program constituted by systematic assessment of respiratory mechanics and gas exchange response. The collected data are then introduced into a registry. We report here the preliminary results.

\section{Objectives}

The QI program aims at facilitating the integration of respiratory mechanics monitoring in ventilatory management. The primary objective of the registry is to investigate the epidemiology of abnormalities in respiratory mechanics in ARDS patients.

\section{Methods}

Two ICUs in Toronto and one ICU in Beijing have initiated this multi-center project. Patients admitted to the ICUs who meet the Berlin definition of ARDS are eligible[1]. Placement of an esophageal catheter is considered when $\mathrm{PaO} 2 / \mathrm{FiO} 2 \leq 200$. Systematic measurement are performed by the clinicians, including respiratory mechanics, lung and chest wall mechanics, oxygenation response to PEEP, and alveolar derecruitment using a

${ }^{1}$ University of Toronto, Interdepartmental Division of Critical Care Medicine, Toronto, Canada

Full list of author information is available at the end of the article simplified decremental PEEP maneuver[2]. After obtaining the first measurement, a comparison of ventilator settings before and after measurements is conducted and we also report the epidemiology of respiratory mechanics abnormalities observed.

\section{Results}

50 ARDS patients have been enrolled (Men: 34, Age: 52 \pm 22 years, SOFA: $12 \pm 5$ ): 7 patients $(14 \%)$ had mild ARDS, 33 (66\%) moderate ARDS, and 10 (20\%) severe ARDS. Esophageal pressure was measured in 46 patients with an occlusion test ratio $(\Delta \mathrm{Paw} / \Delta \mathrm{Pes})$ at $0.94 \pm 0.18$. In 39 patients $(78 \%)$, the ventilator settings were changed according to measurements, often by limiting VT and PEEP. The physiological variables in respiratory mechanics are described in Table 1 . We found that on

Table 1. Epidemiology of respiratory mechanics $(N=50)$

\begin{tabular}{llll}
\hline Variable & Values & Extreme & Unit \\
\hline Pplat & $25(21-30)$ & $13-37$ & $\mathrm{cmH}_{2} \mathrm{O}$ \\
\hline PEEPtot & $12(10-15)$ & $5-19$ & $\mathrm{cmH}_{2} \mathrm{O}$ \\
\hline Vt/PBW & $6.3(6.0-6.7)$ & $3.0-7.8$ & $\mathrm{ml} / \mathrm{kg}$ \\
\hline Pdriv & $13(9-16)$ & $7-25$ & $\mathrm{cmH}_{2} \mathrm{O}$ \\
\hline Ers & $30(22-37)$ & $16-74$ & $\mathrm{cmH}_{2} \mathrm{O} / \mathrm{L}$ \\
\hline EL/Ers & $74(65-80)$ & $48-92$ & $\%$ \\
\hline $\mathrm{PaO}_{2} / \mathrm{FiO}_{2}$, low PEEP* & $143(103-190)$ & $60-311$ & $\mathrm{mmHg}$ \\
$\mathrm{PaO}_{2} / \mathrm{FiO}_{2}$, high PEEP* & $142(118-200)$ & $58-282$ & $\mathrm{mmHg}$ \\
\hline $\mathrm{Vder}^{120(69-200)}$ & $0-426$ & $\mathrm{ml}$
\end{tabular}

Values were described as medians [interquartile ranges], and the extreme was reported as minimum-maximum.

Pplat: plateau pressure; PEEPtot: total PEEP; Vt/PBW, tidal volume per predicted body weight; Pdriv: driving pressure of respiratory system; Ers: elastance of respiratory system; EL/Ers: the ratio of lung elastance to respiratory system elastance; Vder: derecruited volume.

* Assessment of oxygenation response by changing PEEP in $3-5 \mathrm{cmH}_{2} \mathrm{O}$. 
average $74 \%$ of the driving pressure to distend the respiratory system was due to the lung, but with extremes from $48 \%$ to $92 \%$. The ICU mortality was $34 \%$.

\section{Conclusions}

A QI program integrating respiratory mechanics monitoring with ventilator management is feasible, lead to individual adaptations and can provide epidemiological information for better understanding respiratory mechanics in ARDS patients.

\section{Authors' details}

${ }^{1}$ University of Toronto, Interdepartmental Division of Critical Care Medicine, Toronto, Canada. ${ }^{2}$ St. Michael's Hospital, Keenan Research Centre and Li Ka Shing Insitute, Department of Critical Care, Toronto, Canada. ${ }^{3}$ Beijing Tiantan Hospital, Department of Critical Care Medicine, Beijing, China. ${ }^{4}$ St. Michael's Hospital, Department of Respiratory Therapist, Toronto, Canada.

Published: 1 October 2015

\section{References}

1. ARDS Definition Task Force, Ranieri VM, Rubenfeld GD, Thompson BT, Ferguson ND, Caldwell E, et al: Acute Respiratory Distress Syndrome The Berlin Definition. JAMA 2012, 307(23):2526-2533.

2. Dellamonica J, Lerolle N, Sargentini C, Beduneau G, Di Marco F, Mercat A et al: PEEP-induced changes in lung volume in acute respiratory distress syndrome. Two methods to estimate alveolar recruitment. Intensive Care Med 2011, 37(10):1595-1604.

doi:10.1186/2197-425X-3-S1-A507

Cite this article as: Chen et al:: Respiratory mechanics in acute respiratory distress syndrome: a quality improvement based registry project. Intensive Care Medicine Experimental 2015 3(Suppl 1):A507.

\section{Submit your manuscript to a SpringerOpen ${ }^{\mathcal{O}}$ journal and benefit from:}

- Convenient online submission

- Rigorous peer review

- Immediate publication on acceptance

- Open access: articles freely available online

- High visibility within the field

- Retaining the copyright to your article

Submit your next manuscript at $>$ springeropen.com 